P O (51)

座 談 会

\title{
中国紙パルプ産業の現状と将来
}

紙パルプ技術協会 編集 委員会

\section{Round-table talk}

\section{Present Situation and Future Prospect of Pulp and Paper Industry in the People's Republic of China}

\author{
J. TAPPI
}

出 席 者 (五十音順)

雨宮善氏（王子製紙秼・エンジニアリング部 長)

伊東 祐正纸（十条製緍秼・溥務取締役）

大西 光司忯 (王子製紙樕 - 副社長, 角協会理事 長一誌上参加）

大江礼三郎氏（東宗農工大学・教授）

川口利朗氏 (本州製紙懒・会長, 協会理事長)

梯茂男氏（本州製紙桻・取締役・包装システ 么部長)

片食 景一民（紙パルプ技術協会・専務理事・協 会会誌編集副委員長)

楠田洋氏（日本包装技術協会・常務理事）

工藤 昭人代（三菱重工業㑣・重機珹部・主務）

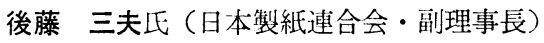

坂本 昇一氏（三島製紙踭・企画開発室長）

奈倉 道博氏（十条製紙㑣）技術調查部・上級技 術調查技師)

福田 祐作纸（王子製紙懒・専務取締役, 協会国 際技術父流委員会委員長)

司会

涴 清庸氏（三菱製紙梸・常務取締役, 協会会 誌編集委員会委員長)
自己紹介と渡中の時期・目的・概要 ・感想など

司会 私, 三菱製紙の浜です。編集委員会の委員長 をやっている関係で，本日の司会をさせて頂きます。

本日は皆さん，お忙しいところをご参集頂き，あり がとらございました。

この中国関係の座談会をやろらと, 編集委員会で決 定した目的は，まず紙パルプ技術協会誌の読者の方々 に, 中国の紙パルプに関する実㮩を十分知って頂き, ひいては中国の紙パルプ工業, あるいはアジアの紙パ ルプに関する工業を日本を中心として大いに発展させ ていきたいということです。決して中国を十分研究し， この際一もうけしようなどといら気はありませんし， また中国の実態からして，一もらけできるような実態 ではないかと思います。

本日は編集委員の方々にも出席して独い, 進行予定 に従って座談会を進めさせて頂きたいと思っています。

今日ご出席願った皆様方の大部分は, 過去において 紙パルプ関係の問題, 何らかの目的で中国にお湾りに なっています。その他特に通産省きっての中国通であ る宮下さん，あるいは紙パルプ技術協会の国際技術交 流委員会の委員長である福田さんをお呼びしているわ けですが，中国との国際交流といらことは，現実に技 術協会として取り上げた場合には，今後とも福田委員 長のいろいろなお世話を得なくてはなりません。

では，まず自己紹介を兼ねて中国に渡られた時期， 目的, 及び概要, 感想などをお願いします。

川口 私はお呼び頁いても資格がないのではないか と思っていたのですが，しかし中国を訪問したという 意味では一番最近かも知れません。6月 4 日に出かけ 


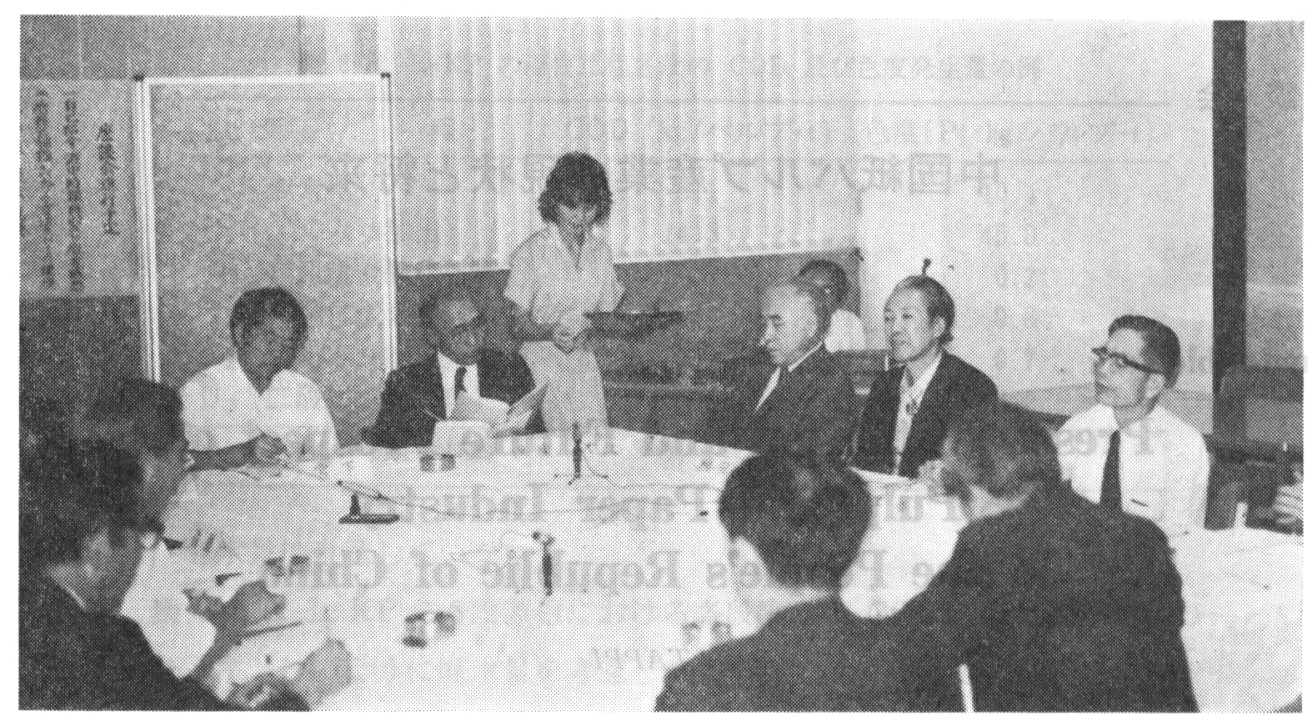

座談会風景

て 8 日に帰ってきたわけですが，その行った主旨は, 銀行主催の, その銀行を主力銀行とする会社のメンバ 一が参加して, 技術には全くと言っていいくらい無関 係な訪問でした。表通りだけを見て回ったといらこと で工場もついに見られず, 例えば国家基本建設委員会 などを訪問して，ご意見を承ってきたといらようなこ とが主ですから, 今日の座談会に出席しても発言の場 がほとんどないのではないかと思います。

私としては, 今日は皆さんのこれまでの中国に関す るご体験を伺うつもりで，楽しみにしてきました。そ らいう意味では誠に申しわけないと思います。

確かに中国は大変だろらと思います。経济的に非常 な悩みを持っており, 訪問の時の委員会の代表の方の 話では, 皆口を揃えて同じような話をしているわけで すが，経済の調整といらことを一番気にしておられま した。といらことは, 四つの近代化といら基本姿勢に は変わりがないのだけれども, 四人組以来, 妙なひず みが出来てしまい, このままではやっていけないので, 少しバランスをとるために行き方を考えるのだという ことで, 重工業を主体としてきたのを一四つの近代 化, つまり農業, 工業, 科学技術の進歩, 防衛の中で, 農業をとにかく主にしていく, これがすべての基本で ある。これは毛沢東の思想であったといらようなこと から始まって, そのためには軽工業を盛儿にしなけれ ばならない。またそのためには重工業を，といら意味 で, いろいろな経済活動をこれから調整していくのだ ということでした。

従って，今までの行き方が方針としては変わったわ
けではないのだけれども, 今まで多少ウェイトが偏し ていたものを，実情に即して，これから中国の経済を 急速に発展させていくためには, そらいら方向でやっ ていくのであるといらことでした。例えば宝山の製鉄 所のスローダウンも決して方針が変わったのではない, 基本方針には変わりがないといらことを誤解しないで もらいといらことを, どなたも強調しておられました。 事実，メインストリートを通っただけですが，先立 つものがなくて，いろいろなことを計画するのは非常 に難しいのだろらな, どこかに力を入れて，どこかが 拔けてしまったら, すぐにボロが出てくるといらこと で, トライアンドェラーといらものが繰り返されるの が本当の姿ではないかといら気がしました。紙パルプ 関係について, 特に知識は得て来なかったのですが, これについても大体同じような行き方が，これからの 道ではないかと感じました。

大西 私は昨年（昭和 53 年）11月 8 日から 28 日ま で正味 2 週間, 中国の 6 つの製紙工場を参観し, 北京, 天津では, 特に今後の技術協力の具体的な方法につき 自由討議を行いました。

中国訪問は私にとって初めての経験ですし, 中国に 関する知識は残念ながら極めて乏しい私に中国を語る 資格はありませんが，専門の製紙工業に関し，また私 の歩いてきた範囲と扮付合いした人達を通して知った 中国の印象をお話ししたいと思います。

私の訪問した時期が, 丁度, 日中平和友好条約が発 動した直後で, 鄧小平さんが日本を訪れて東京を中心 に各地を訪問している状況が, 逐一衛星中継され, 中 


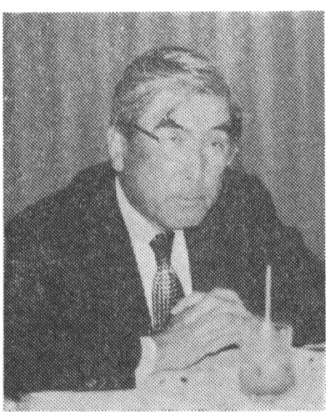

濱氐

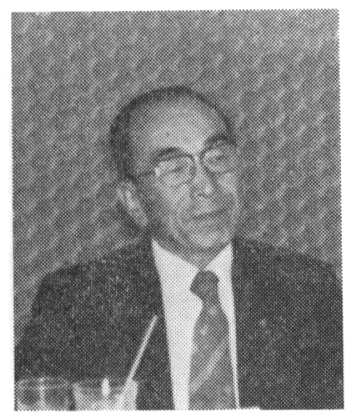

川口氏

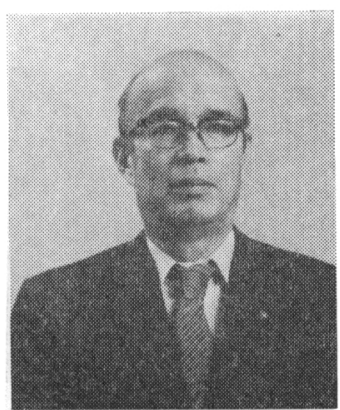

大西 氏

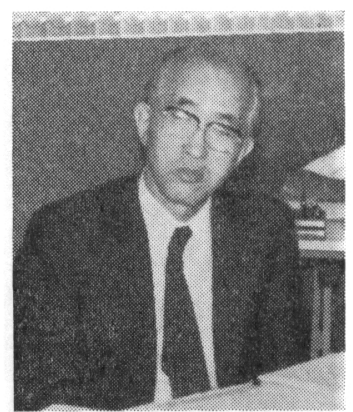

伊東氏

（発言順）

国の人達が日本の進んだ実態を初めて紹介され, 親日 的な子ん用気と共に日本の技術を学ぼらといら気分が みなぎっている時でした。彼等の合言葉である「自力 更生」「農は大寨に学び, 工は大慶に学べ」といらス ローガンは別におろした訳けではありませんが, 決し てこれにとらわれず，技術の遅れを取戻すためには， 国の主権を損なわない限り，あらゆる方法で，どこの 国からでも導人したいといら熱意が随所にらかがわれ ました。私達は広東省 (広州造紙淘) から始まり, 浙 江省 (紅旗, 東風造紙廠), 上海 (江南, 紅衛造紙硝), 天津 (天津造紙僘) と順次北上して, 最後に北京で総 括的な討議を行いました。全日程にわたって, 北京か ら派遣された製紙関係の理事と女性通訳が同行し, ま た各省の軽工業局から世話係が派遣されて, その省に 滞在している間中，紐かい連絡や段取をすべてやって くれたので, 全く安心して旅行が出来ました。

工場を訪れると, まず入口には「熱烈歓迎」の幕を 掲げ，工場幹部が拍手で迎えてくれます。お茶を飲み ながら, 工場の概要を説明し, 工場の中をくまなく案 内してくれて, 事務所一戻ると早速質疑応答が始まり ます。参観の結果気が付いた点を何でもアドバイスし てくれと言います。通り一辺の感想を述べるだけでは とても勘弁してくれません。それではといらわけで, 気の付いた点を断片的に話すと, 体を乗り出すように して熱心に聞き,メモをとる人もいます。その熱意と 謙虚さは大したものでした。ただし,す心゙て中国語の 通訳を介して技術談義をやるので, 時間が 3 倍も余計 にかかり，いつも時間ぎりぎりまでやって，急いで工 場を辞去するといらことを繰り返しました。

特に広州造紙厰では, ……こは馬尾松といら松を 原料にしてパルプを作り，新聞用紙を中心に日産 300 $\mathrm{t}$ の紙を作っている工場ですが……, 主力マシンのス ピードアップについて, 図面をひろげながら, 随分と
具体的な意見の交換を行いました。

伊東 十条製紙の伊東です。私が参りましたのは, 今から 5 年前の 49 年の春で, 製紙連合会の 中国への ミッションといらよらな形での訪問でした。その目的 は，ここにおいでの後藤さんが詳しいので, 後からご 説明になると思いますから省略させて頂きます。

も5 5 年になると大分記憶が薄れ，実はこらいら所 几出てお話する内容もないのですが，私共が参りまし た時は 6 力所の工場を見学しました。天津で 2 力所, 上海で 2 力所, 広州で 2 力所です。ミッションで行っ ているので向こうとしてもなるべくいい所を見せてく れたのだと思いますが，実態をわれわれの感じから申 し上げると，やはりまだ日本で言えば昭和 30 年にち 上っと足がかかったかなといら程度の技術レベルでし た。生産 $\mathrm{t}$ 数から見ても, 原料が木材でないといらの が大部分なので，非常に小さく，15t とか $20 \mathrm{t}$ とい ら工場もあります。広州で $200 \mathrm{t}$ 位の新聞用紙工場が 1 力所ありますが, 後は大きくても $70 \mathrm{t}$ 位です。マ シンも $3 \sim 4$ 台, 小さなマシンを持っているといらの が大部分です。

そらいらレベルから見ると，日本が技術交流をした いといら状態では，まだないわけです。といらのは, 私共が行ったのは, 特に中国からの要請があったので すが，日本と中国の間に技術交流をしたいということ で，われわ机方もいろいろな資料をそろえていった わけです。例えば, 紙のクローズドシステムについて の話をするとか，コーターとかサクションフォーマー の話をしてくれといらことで, こちらから技術屋が 4 名行ったので, おのおの分担して各工場で講演をやっ たわけです。そして向こらからの質間があれば答える といら予定で行ったのですが，レベルの相違があり， いわゆるディスカッションといら形には全然ならない。

技術交流にはならないわけで，一方的な話になり， 


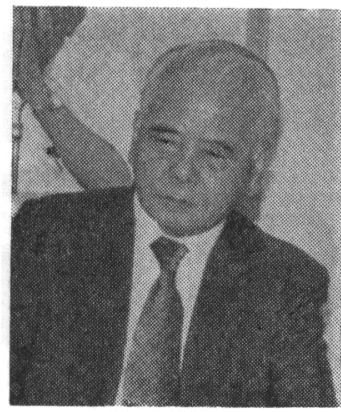

渡辺 氏

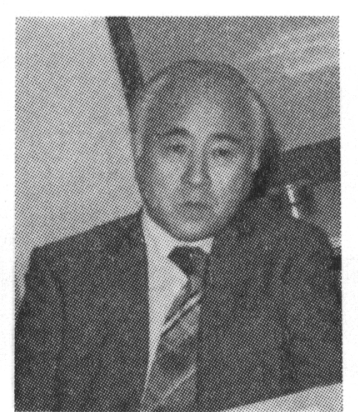

大 江 氏

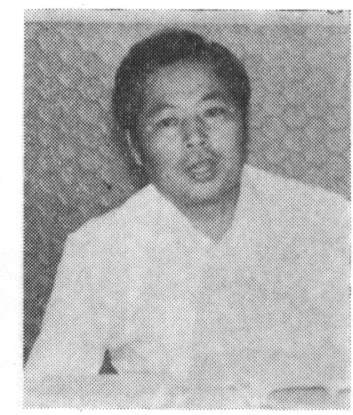

宮下氏

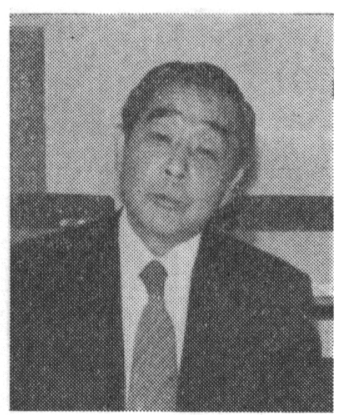

後 藤 氏
どれだけの反応があったかについてもサッパリ分から ないといら状態で州ってきたのです。そらいうレベル ですので, まだ一方的に教えるという立場にあると思 います。

それから何しろ規模が小さい。それに対し，1つの 工場に人間が 2,000 人も 3,000 人もいる。つまり 30 〜 40 t しか作っていない工場に何千人もの従業員がい るといらことで，まだ合理化を考える時代でもなく， あるいは公害の問題 1 つとらえても，その心配をらん 妨するよらな時代でもないといら印象を持って州っ てきました。

渡辺 日本加工製紙の渡辺です。今拉話になった伊 東さん, 撛りにいらっしゃる後藤さんの後圭ついて 5 年前に行ってきたのですが，何分にも 5 年前のこ上 で記憶も定かでないといら状況です。

私達, 帰って来て, 技術屋同士でリポートを出し合 い，それをまとめて紙分技協誌汇報告を出しました。 今, 伊東さんからも扔話があったように, とにかく技 術格差は 2 30 年前, 20 年といらより 30 年と言った 方がいい位です。 5 年前に行った特では, ビーターを 盛しに使っていました。

それと従業員の数が非常に多い。大体日本の10 倍 位使っているんじゃないかと思いました。ただ給料が 安いといらこともあるでしょうし, 皆働かなくてはい けないといら国だから，そらいらこと去っているの だと思います。

も51つ交通ですが，国の大きい割りには発達して 扔らず, 従って大きな工場ができるのは無理なのでは ないか。だから小さい工場をその土地その土地に作り, その地方を洞すといら程度ではないかと思われ，その 工場の成り立ちといらものが，その地方でできた原料 を主として，その地方を潤す物を作っているという感 じの工場が多かったように思います。

それから実際，中国の紙関係を知るのであれば，私
たちは天津から始まり, 広州までの 6 工場だけでした が，東北地方を見ないと本当のことは分からないので はないかと思います。パルプなどはスウェーデンなど からの輸入がほとんぞで, 東北地方からもパルプは来 ているのだと聞いていながらも，それは見たことが余 りありません。これもやはり交通の関係, 原料の関係 等があり, これからどらいらふらにやっていくのかと いら方針を決めるべき時期であるという状態です。

大江 東京農工大学の大江です。私は昨年の 6 月, 技術交流会に参加しないかといらお話があったので, 三島製紙の坂本さんとご一緒したわけです。私は以前, バングラディシュで 1 年半程, 竹パルプの仕事をした ことがありますが，中国は 750 万 $\mathrm{t}$ の紙の消費があり， かなり非木材を使っているといらことで，大変興味深 く思って行ったわけです。

なかなか大きな国ですから，目をつぶって象を触る という感じで, 分かりにくい所が多くありました。1 人当たり 1977 年, $9 \mathrm{~kg}$ 位の紙の消費があったといら ことですが，実際にそんなに沢山使われているだろう かといら感じがしました。またその原料の方も，草本 が多く，竹の子の皮を使っている所もあるといら状態 です。最近修正になったよらですが，近代化政策で今 後生産が倍增する場合には, 原料問題が大きなネック になららといら気がします。とにかく分からないこと がたくさんあり,むしろこの機会に皆さんのご印象を 伺いたいと思っています。

宮下 通産省紙業課の宮下です。個人的なことで申 し上げると, 40 年に通産省に入った時から, 趣味と して中国問題を勉強しようと思い始めました。直接の 関わり合いで申し上げると，46 年から50 年まで通商 政策局北アジア課という通産省での対中国貿易の空口 課におりました。その間 48 年 5 月から 49 年の 1 月ま で 9 力月間, 北京に駐在しました。

その後も一昨年までは, 毎年のように 1 回行ってい 


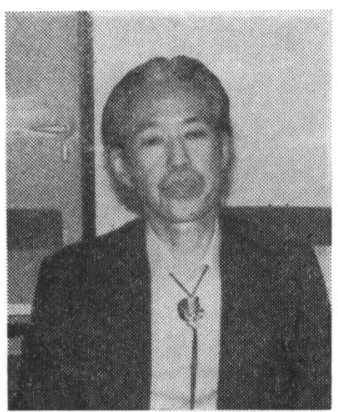

楠田氏

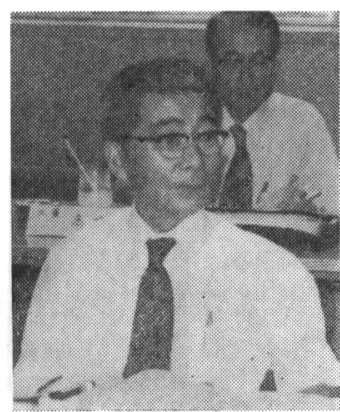

梯氐

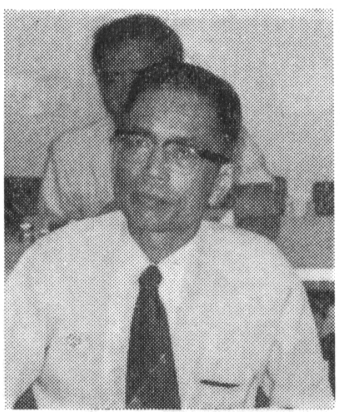

工. 藤 氏

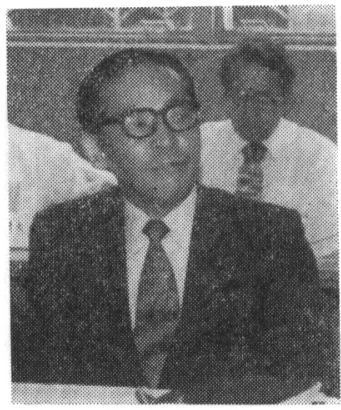

坂本 氏
たのですが，この $2 \sim 3$ 年は行っていません。特に紙 業課に来てからは……しかし今でも関心はあるので すが，紙業課の業務が忙しく思うようにいきません。

関心の対象といらのは, 私個人的には中国の工業, 技術の発展に興味を持っています。ご承知のように， 中国は統計資料等の公表が少ないですから, 学者の方 々もなかなかつかみにくい。むしろ現地関係など経験 する方が面白く, アマチュアでも趣味としてはとりつ きやすいと思っていたのです。ところがやってもやっ ても難しく, 今だにちっとも分かりません。今日はい ろいろ教えて頂けると思い喜んで出席しました。

後藤 先程ご案内があったよらに，昭和 49 年 3 月 に製紙連・海堀ミッションの一員として中国に行きま した。このミッションの性格は, 対中国の貿易の空口 となっていた中国軽工業品進出口総公司, これは国営 貿易会社なのですが，そこからの招へいがあり，総員 18 人で行ったわけです。

共産圈に対し，業界ぐるみでミッションを派遣した のは初めてで, 特に技術屋の方も加わって㙺易交流の みでなく, 工場での講演, 説明その他技術指導を行っ たわけです。

訪中直後は北京の軽工業品進出口総公司, そこの主 脳に対する表敬訪問と, 中国国際貿易促進委員会の計 2 力所を訪問すると同時に, 日本側の製紙事情及び貿 易対応の姿勢についての概要をお話しました。それか ら中国側の製紙事情, 輸入見通しなどを聞き, 引き続 いて従前の貿易に対するお礼をかねて貿易交流を今後 とも前向きに進めたいという意志を伝えたわけです。 あとは技術指導点含めた 6 力所の工場見学の案内をう けました。

もう5 年前の話で, その後随分と目まぐるしい情勢 の変化がありました。四人組などの問題もあり，相当 中国の事情も変わってきたと思います。ともかく私共 の当時の印象としては, ご参加の皆さんとも後でお話
ししたのですが，大きな困難を克服しながら黙々とい らか着々といらか国造りを進める新中国と人民の姿を 大きく評価もしました。豊富な資源, 労働力を考える と, やはり相当強い将来を期待できる国家になるとい ら印象を当時も強く受けましたし，また最近の情勢， 報道等から察しても, 社会体制の違ら国の未知の無気 味さもありますが，この当時の気持ちは変っていませ h。

当時困ったのは, 中国側の経済, 産業事情を説明し てもらいたいと思ったのですが, 統計的, 具体的数字 の公表は極く一部であって, 私達が州国した後でもか まわないからデータが欲しいといっても, その後にお いても，特に回答のなかったことです。紙・板紙の生 産量を例にとっても, 私達が行った時に 1973 年で 400 万 $\mathrm{t}$ 弱と言われましたが，その後 $\mathrm{FAO}$ などの資料を 見ると 600 万 $\mathrm{t}$ とか 650 万 $\mathrm{t}$ といら数字が出て来まし た。ごく最近，中国の軽工業大臣が日本に来て，その 時私共のレクチュアに対しての回答の中に 1978 年の 紙・板紙の生産量は 430 万 $\mathrm{t}$ とはっきり申されました。 あるいはこれが正しいのではないかと思います。

それから事前に協会の片倉専務からも中国側の貿易 に関する組織はどうなっているのかというお話があり ましたが，政府の関係としては先程の軽工業部と対外 貿易部といらのがあります。これは日本流でいらと軽 工業省は通産省に当ります。それから経済企画庁的な もので, 国家経済委員会があり,軽工業部は質易に対す る政策面をやっています。以上が大体の官庁機構です。

それに対して民間組織として，いわゆる国営会社の 軽工業品進出口総公司というのがあり, 紙・板紙など の貿易の空口となり，一括購入という形をとっていま す。この裏加ら総合経済的に政策的に, これらの官庁 が管理や针告をしています。

軽工業品進出口総公司は, 各主要都市に分公司を持 っており, 私が知っているだけでも, 北京, 天津, 上 


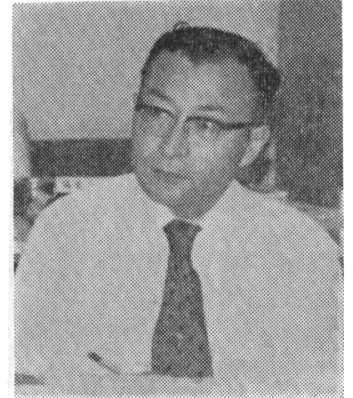

雨，宮氏

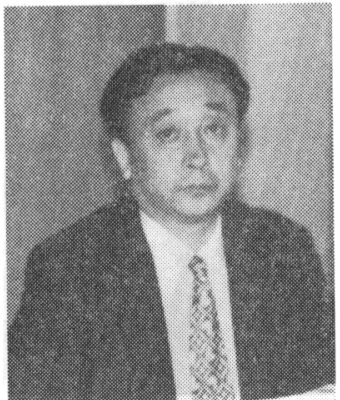

奈合 氏

海, 広州とあり, それぞれ相等な権限をもって地域的 な活動をやっており，それを北京の総公司が統括して います。

楠田 私は今年の 3 月と 7 月と 2 回中国に行って来 ました。3月に行ったのは, 対外貿易部関係で, 中国 の輸出包装が非常に悪い。つまり売っても売ってもク レームがっいて返ってくる。何としても中国は外貨を 稼ぎたいのに，包装が悪いためにそれができない。こ れは内装と外装と雨方問題になるわけですが, デザイ ンも悪い。とにかく包装を改善しなければ，何をやる にしても問題が解決しない。ということで, 包装技術 協会で全面的に包装竞見てくれといわれたのです。

対外貿易部の中に，中国出口商品包装公司といらの が，北京に総公司，各地に分公司があります。その5 ち天津分公司が中心となり，とにかく来てく机という ことで，私一人 3 月に行き，下調べをした上で，この 7 月 17 日から，梯さんにもご一緒をお願いして，8 名で行ってつい先日带ってきたばかりです。

今度は天津と北京，上海と大变熱心な技術交流があ り, 六地区から 95 名の人が集まり, 講師と受满者が 一体となって技術交流に励みました。いろいろ工場も 見せて貪いました。

梯 本州製紙の梯です。今, 楠田さんが言われた通 り，7月 17 日から 29 日まで一行 8 名で楠田さんのお 供で行ってきました。主に向こらでしたことは, 技術 交流については, 彼らの輸出包装を改善するためにど らあるべきかといらことなのですが，包装といっても 筑用が非常に広いので, 一応は対象を輸出にしぼった ものの，国内での商品の包装も含めて，いろいろの立 場の方達が分担して, 連日 5 講座開き, 100 人の受講 生に対し, 20 人ずつのクラスを 5 つ作り, それに通 訳の方に入って貫って, 包装のデザインの問題, 標準 化の問題，ダンボール包装はどうあるべきか, 包装紙 器印刷についての在り方, プラスティック包装, 食品

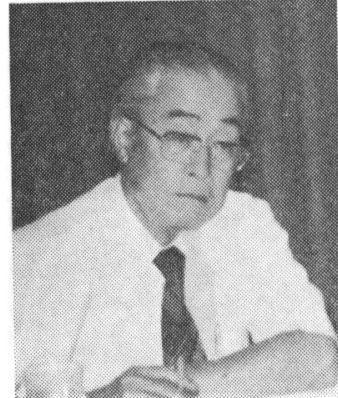

福田氏

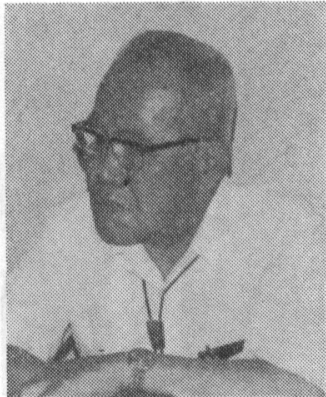

片倉氏
包装, 緩衝包装といらいろいろなテーマで， 5 日間 5 クラスを受け持ちました。約 $7 \sim 8$ 割はこちらの講演 ですが，十分に質問時間をとり，彼らとディスカッシ ョンもしました。

それからこの包装技術交流に先立って，われわれは どの程度の話をしていいか分からないから，包装に関 する中国の現状を十分視察させてくれといら注文を申 し入れて扔いたので, 講演の合間に 5 力工場, 天津の 新港の荷役関係, 流通関係, 船積みも含めて 6 回の見 学をやりました。港が 1 つと段ボール工場が 1 つ, 紙 器印刷が 1 つプラスティックのブロウの工場並びに プラスティックの印刷の工場 1 つ, それから食品工場 も見せてくれる予定だったのですが，手頃なものがな く，ビール工場をそれぞれ見学してから，アドバイス する時間をとって鿓って講義をやってきました。

極く大ざっぱに言うと，紙の包装に関する加工とい らものは, プラスティックの加工より非常に中国では 罣れています。日本よりは無論低いのですが，紙より プラスティックの方が，まだましなかっこらをしてい るといら状態で，これから紙の加工関係は相当急速に レベルを上げる必要があると思います。

今回は，包装に関しては第 1 回の技術交流であり， 今後むこらからも来るでしょうし, こちらからも再度, 第 2 回, 第 3 回といらことをやって, とにかく 1 回で レベルが上がるものではありませんし, 根気よくやっ ていこらではないかといら懸度でいます。向こうもそ 机に賛成で, 日本人と違って非常に気が長いですから， ガッチリと取り組んでいけるのではないかと感じてい ます。

工藤 三菱重工の工藤です。私は昨年 (昭和 53 年) の 6 月から 7 月にかけて北京に行きました。これは中 国技術進出口総公司，いわゆるプラント類を輸入契約 する空口です。ここの招きで, 紙パルプ工場の建設, すなわちパルプ機械, 製紙機械, プラント建設の技術 
交流といらことで行きました。

その後 54 年 2 月, 3 月にかけ，上海上北灾に参りま した。上海の方は国貿促経由の技術交流で，これは一 般技術交流として行きました。その後北京の广は, 輅 下:業部の下湖機構である㹩工業建設公司, いわゆる愢 厂業蔀沂管品目の土場建设を担当する組織があるので すが，それ上愢工業制造紙局の招きで行ってきました。

それから今年の 7 月 1 日から 25 日まで, 同じく造 紙归と建没公司の据きで, 上海, 湖南省, 北京, 福建 省と问ってきました。その間製紙工場は, 今春は上海 市内の工場を 2 力所ばかり見学し， 7 月は地方の工場 を2 カ所ばかり見学しました。

今年 4 月から 5 月に, 先程後藤さんのお話にあった 怓工業考察团が来た時には，国家経済委員会の王文哲 局長はじめ 4 人程, 私共の工場へ来て頂きました。王 文哲さんは 15 年前にも日本へ来られており，かつて 造紙局長もされた方です。その時にもお目にかかって いろいろお話しできました。

私の感想としては，工場建設の話ばかりで行ってい るのですが，第 1 回目，昨年 6 月から 7 月にかけて行 った時は，伊東専枒のお話のように反応がサッパリわ からなかったのです。ところが问こうから来たり，そ の後こちらからも2 回行ったりで, 何回も会っている らちに次第にうちとけてきて, ある程度の技術レベル が分かってきました。そして今では彼らがどういう身 分，経㾚であるかも少しずつ分かってきました。

それから今年の春頃は先程の調整といら問題をしき りと強調していましたが，今年 7 月に行った段階では， 4 つの近代化のうち, 軽工業は優先されるべきものだ といらことで, 工場建設に対してものすごく熱意を然 やしていました。今後そういう話が起こってくるので はないかと思います。

ところでわれわれの圷場として間題になる，工業所 有権の問題がありますが，これについても彼らはどう いう条件であるとか，いろいろ細かいことを聞き出す ような状態になってきました。昨年と比べると, 大分 この 1 作間に進歩が感じられました。

坂本 三島製紙の坂本です。私はやはり胙年の 6 月

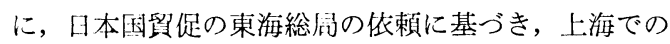
技術交流会に先程お話が出た大江先生とご一緒に行っ たわけです。州路北京で工藤さんにもお目にかかりま した。

技術交流会には上海周辺だけでなく，北京あるいは 天津からも集まってこられた工程師クラスの方を中心 とした技術交流会を 2 週間にわたってもったわけです。 地方からお見えになっていた方もあったので，半日
座談会をやり，半日は私峷が备方面を罗䇰している間， 彼らは钨㼁したり，あるいは自分たちも上汻人よって きたわけですから，务方面学見していました。坐談 会の最中，われわれの専門語はどうしても英語化して いるので，通訳の方がほ上んど，英語の朗衙すら利ら ない上いうことで非嫦に困りました。幸いなことに，

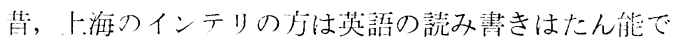
すので，垈配の工程皈の方が英話を中国語に直し，ま た中国語同志でトランスレイトしているという光熟に 何度かぶつかりました。莒葉の問題は非常に大きいと 思いました。

それから私達が行ったのは，丁度日中平和条約を䋨 䋐する前だったので，どちらの方面に行っても非常に 友好的なムードでした。中国の方々もわれわれのこと をよく知っていて，备方面でいろいろな方に割合簡笚 にお会いできた点はよかったのではないかと思ってい ます。

雨宮 私はまだ中国は駆け出しで，昨年 7 月にある 㨐社系の社長さん方のグループが経済交流に行くよい うことで，その随員として行きました。その㭙は李先 念副主相と人民大会堂で会ったり, こちらはくっつい て歩くだけのことでしたが，非常に印象深い統括的な 大きなお話がありました。

その後，らちの社長のその時のお話で，製紙関係の 技術交流をしたいといらことが，軽工業部と同意され て大西副社長が団長で，先ほどお話がありましたよう に11月に南の方から入って，6つばかり工場を視察 し，北京で総括的な技術交流を行ったわけです。それ にまた尾を引いて, 今年の 4 月から 5 月にかけて, 東 北地方, 天津等, 勃海湾の環境改善に関連する製紙工 場の排水対策ということで各工場を見て回り，特に天 津では SP の廃液はほとんど垂れ流しなので，これを いかにするべきかというディスカッションを約 10 日 程やりました。

中国の方々の印象といっても，ほんの一部の方とし かお会いしていないし，一部しか見ていないので，全 部を推定するのは危ないのですが，とにかく勉強熱心 でとことん聞きます。そしてむこうも数尔はとことん 公開するということで，とにかく站くしたいといら熱 意は大変なものでした。

また， 2 度の工場見学旅行で一番感じたことは，各 工場に大きな機械工場を持っていて，スーパーカレン ダーのロールは自分の工場で作る。あるいはペーパー マシンも 100 in クラスであれば全部, ドライヤーの ちゅら造までやって作るということで，50t/日位のぺ 一パーマシンならほとんど問題なく自国製でやれ，か 
なりあちこちでペーパーマシンの増設工事が行われて いました。

また，木ガマも素材だけは，クラッドスティールを 買ってくるけれども, 成型及び溶接は全部自分の所で 進めているといらことで，製紙工場の大增設はどんど ん進んでいると思われます。

奈倉 十条製紙の奈會です。私は炤和 50 年の 11 月 から 12 月にかけて 約 5 週間，日本工業技術展覧会齐 北京で開いた時，日本製紙連合会の方から参りました。 これはJETRO主催でしたが，説明役をやりました。 それが終わってから，漢陽の造紙廠，広州の造紙啟一 見学に行きました。武漢にある漢陽は楊子江の上流 $800 \mathrm{~km}$ 位のところですが, 武漢に到着してから私た ちが見学したいと要請し, 連れていかれた工場は年産 4 万 $\mathrm{t}$ 位の工場で, 湖北省には, これ程大きいのはこ こしかないとのことでした。楊子江の上流, 下流にも 目立って大きい工場がないのは, 下流で生活用水にし ているからで, これから増設するにしても，活性励泥 で徆の排液を処理したいとか, 公害の問題で行き悩ん でいるという話を聞きました。

原料は楊子江のアシ，竜䰅草という強靱な繊維を持 つ草本の植物をソーダ蒸解して作っていましたが,こ の代表的な工場が年産 4 万 $\mathrm{t}$ 位。゙すと，1975年当㭙 豆われていた年産 690 万 $\mathrm{t}$ 位紙を作っているという们 はちょっと多すぎるのではないかなと思って州ってき ました。

この 6 月末に中国の第 5 期全国人民代表大会で, 公 表された統尌では 439 万 $\mathrm{t}$ の紙及び板紙が 1978 年に 生産され，前年比で $16.4 \%$ 增加したといいます。こ のことから私共が行った昭和 50 年顛はやはり 300 万 $\mathrm{t}$ 位ではなかったかと思います。

そして北京から南へ $1,000 \mathrm{~km}$ 京漢線で下がったの ですが，その間，貨物列車に全然すれ湋わないのです。 複線ですが……湖北省の武漢でいろいろ聞いても, 月分の省のことは自分の省で賄なら, 衣料でも紙でも そうだということで，人民日献でも非常に瑟い紙を使 っていました。武漢あたりでは紙の消費量が当時 1 人 当り $8 \mathrm{~kg}$ 位だと言われていたのが，実際は今年公表 された統計から割り出してみると, $4 \mathrm{~kg}$ 位です。製紙 に関しては, 終戦淔後の日本のように逯れた印象をも って䚻りました。工場へ入ってもステンレスが全然な く, 素焼きの土管, あるいは陶磁器のさらし用のパイ プを使ったり，あるいは鉄パイプだけでアルカリ蒸解 したようなパルプを扱ったりしていることからこれ からが大変だなと思いました。

福田 王子製紙の福田です。今日お集まりの中で,
戦前戦後を通じて中国と何の関わりも持っていない唯 一の人間です。夷は先程ご紹介にあったように, 協会 の技術交流委員会の委員長を承っており, 現在のとこ ろはカナダ, アメリカ, あるいはその他の方わば製紙 における先進国との技術父流に, 主として目をむけて いるわけです。先程来皆様方のお話を同っていると, いずれは中国との技術交流——現在のところはどうも 技術交流というより技術指覚といら方が言葉としては 洁しいのではないかといら印象を, 先程から受けてい ますが，いずれは交流という段階になるだろうという こともあり, 今日は皆様方のお話を同って, 将来の技 術交流の参考にさせて頂きたいと思っています。

\section{原料の種類とパルプ化の方法及びその規模}

司会 紙パルプに関しての中国との関係は私もゼロ ですが，福田さんと違って，私は 10 年中国に滞在し ていました。小学校 2 年から中学を卒業するまで, と いらことで中国が非常に懐しいのですが，中国のその 牌の産業状態がどうであったかということはほとんど 分かりません。

では続いて原料の雬類とパルプ化の方法及びその規 模ということに入っていきたいと琹います。

大西世界の大部分の紙パルプ工場が木材を原料と しているのに，中国ではその70\%を稻ワラ，麦ワラ， アシなどの禾本科植物に依存しているので, 原料の集 荷, 運般, 荷役, 則蔵などの面で, 大規模な, また近 代的な工場が作れません。他の産業でもそうだという 活ですが，中国では工業を全国土に分散配置する方針 をとっています。その結果, 地方で利用出来るワラや アシを使い, 日産 $1 \mathrm{t}$ から $10 \mathrm{t}$ という小規模で, 手工 業的な製紙工場を無数といってもいい位作りました。 もちろん，これには別の理由もあります。

製紙用原木は東北地方……昍満州ですが……佁東， 穴西あるいは奥地の諸州に螎在していて, 中央地带に

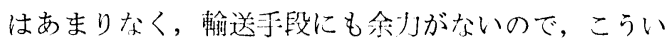
らことになったのだとも菏えられます。

大江 先积後藤さんから1978年の紙・板紙の消費 が430万t といらお話がありましたが，私としては大 変納得のいく数字です。統计的では文化大革命故から 非常に生産が伸びたことになっておりますが，どうも 疑問に思っておりました。国内総生産 1,000 ドル当た り，社会主義国は $15 \mathrm{~kg}$ 位といら統姑がありますから， そういう点からみても，今まで、命われていた 1 人当り $9 \mathrm{~kg}$ は多いと思います。

それにしても人口が非常に多いので, 総生産量は非 常に多くなると思うのですが，広いと言われますが， 
耕地面積 1 つとっても 1 人当たり 1 畧（ムー）といい ますから 200 坢位で，日本の農家よりもずっと 1 人当 たりでは少ないといらのが央情です。森林も 1 人当た りにすればかなり少ない。従って非木材が多く使われ ているわけです。私もいくつかの工場を見ましたが， ワラとが桿, 竜髹草 (エスパルトのようなもの), 竹，竹の子の皮まで使っているという状態です。こう いう非木材は，例えば竹にしても，インド，バングラ ディシュもそうなのですが，木材に比べて伐採コスト， 輸送コストが割高になり, 決して安くならないわけで す。ワラも日本の場合では木材チップより非常に割高 であるといらことです。

そういう点で非木材は収集, 輸送, 聍蔵にコストが かかる材料だと思うわけです。

いい意味では, 中国はそういう材料の使い方にはか なり経験が深いと思います。というのは, 上海の新華 書店で崱った本で, バガスパルプの教科書があります が，バガスのリグニンの構造から，紙の製造まで全部 出ています。なかなか科学知識も充実しているように 思います。そういう面では小さなプラントを数多く作 るという，いい意味ではデセントラリゼーションとい うことで進めていくのかと思いますが，一方，8年後 までに生産を大幅に上げるというようなことになると， とてもそれでは間に合わないのではないかと思います。 この过の兒方ですが，私は紙パルプ技術予測研究会 で原料分科会を担当しているのですが，皆さんにアン ケートをして, 中国では FAO の統計では 1 人当たり $9 \mathrm{~kg}$ の消費があるが, 世界の平均 $30 \mathrm{~kg}$ 位になるの は何年先かとお聞きしたら，回答が 2 つに割れて，中 国に行った方は比較的遅い時期を考えておられますが， 一般の方はかなり早い時期に実現すると見ておられま す。この場合だと，かなり短期間に生産が上がってい くわけで，今までの中国の製紙技術の行き方とまた違 ったものになってくると思うのです。この辺をどら考 えていくか,むしろ工藤さんあたりの方が詳しいと思 うので，ご意見を伺いたいと思います。

工藤 昨年の生麾 439 万 $\mathrm{t}$ といらのは聞きました。 そのらち木材が原料として $30 \%$, 草類が $60 \%$, 古紙 が 10\%，これも大体命まで聞いていた話です。では その草のうち何を使っているか，順序を並べてくれと いったら, 麦ワラが一番, その次が稲ワラ, アシ, バ ガス, タケ，その他芒桿などが出てきます。

ところがこういう草本植物を使ったのでは倍増など できないのではないかと，いろいろ向こうと話をして いたのですが，今中国内では植林をものすごくやって います。ここしばらくは森林を保護するために, 木材
を使っての工場は，これ以上增やさないようある程度 制限しているらしいのですね。その間は草類をできる だけ利用する，それがどらも当面の方針のようですね。

あとは黒龍江とか，献の方に木は確かにあるようで す。しかし, 伐採と輸送が伴っていないので, 出そう にも出せないというのが実態のようですね。ですから いろいろ国家計画，並びに各省単位で計画をたててい るようですが, 工場を建てても原料が供給できないじ やないかという問題がいろいろあって，国家規模でま だ調整を相当やっているようですね。物はあるけれど も出せないという状況のようです。

それから今はまだ引き合いといらところまでいって いない話が随分あるのですが, 将来例えば草の関係で プラント建設という場合にも，木材に転換できるよう に考えるといらことまで言っていますね。439万 $\mathrm{t}$ と いら数字は, 統計的に表われる数字であり, その他に 人民公社内で自製しているようなものが相当あるらし く，それがどの位かといらのが，聞く人によって， 100 万t 位といら人もありますし, もっと少なく言ら 人もあります。実態は 439 万 $\mathrm{t}$ よりは多いのではない かと思います。

とにかく 1985 年までに倍增したいと，むこうは䓀 っているのですから，それならチップでも輸入しなけ れば到底不可能ではないかと言っているのですが，金 がないといらのは大きな問題ですね。

司会 植林面積はどの位ですか。

工藤 とにかくハゲ山みたいな所に一生懸命植えて いますね。南と北の両極端以外, あまり緑の山はない ですね。

司会 今頃植えても, 1985 年位まででは大して 伸 びないでしょう。

渡辺わりと成長の早い木のようですよ。

川口地域的に気象条件も随分差があるんじゃない ですか。奥の砂漠の方へ行ったら雨量も少ないでしょ うし……。ただ,今砂漠らしくなっている所でも,そう いら所は植林していくといらようなことは言っていま したがね。面積はどの位かわからないけれど, 全体が 日本の 26 倍半だから, その半分でも大変なもんです。

工藤 これが馬尾松の葉です。これは広東, 広西, 福建, 湖南, 四川の 5 省がほとんどですね。

川口 15 年位で切れるのですか。

工藤 そうですね。あまり高い所にはありません。 これは今年の春聞いたのですが, 1985 年まで倍増す るといら目標に対して, 北京の幹部はものすごく悲観 的ですね。絶対できないと……

川口 私も質問したんだけど，条件のいい所なら 7 
年か 8 年で伐採可能になるから余程力を入れてもいい ビゃないかと言ったら，そのつもりでやっているんだ といらことは言ってましたけどね。

宮下さっきの植林面積ですが，中国は今年になっ て初めて, 77 年と 78 年の統計を比較的詳しく出しま した。余談ですが，1958 年までは揃しく発表してい ますが，それから 77 年まではお拉む㸚刘前年比だけ， それも伸びている時だけで, ダウンしている時は出し ていないのです。それを推計していくと, かなり高目 になってしまいます。で昨年の植林面積は全国で 449 万 7 千 ha，前年比 $6.2 \%$ 減です。

全体の山地面積はちょっと見てないのですが.......

楠田 私は 30 何年前, 黑龍江の 完達山脈にいたの ですが，随分沢山あるんですから，あれを生かすとい らことは考えてないんですかね。製紙工場は向こうに はないんですか。

川口 東北は昔から本場だったわけで.......

後藤 5 年前行った辞では, 大規模な工場は 10 あ り, 東北地方に 7 つ。とは四川と河北と広州に冬 1 工場ずつあるとのことで, 土法による日産 1〜 $5 \mathrm{t} の$ 小型工場は，例えば人民公社に付属するなどして，全 省僻地に 1,500 2,000 ぐらい分散していると聞きま した。

次でに生産工場のことについて申トげますと，前问 訪中の際, 説明をうけたことなんですが，中国の大部 分の工場はフル操業, 深夜操業で三交替制をとってい ます。ですから一見異常と思えるほどの従業員を抱え ていますね。工場での管理組織としては工場革命委員 会といらものがあって, 学㗢, 技術, 指尊幹部の三つ のセクションから代表委員を選出して送りこみます。 これが工場の指導グループとなっています。

計画経済にそって年間生産計画が, 先ほどの国家経 済委員会や軽工業部などから下がってきますと, 計画 详成のための十分な討議が行われて, 決定しますと上 部革命委員会の批准をうけるそうです。

この段階で原料や資材の割当て, 製品価格, 納入先 なども決ってくることが通例とのことでして，例えば 広州造紙僘の場合は中央の軽工業部の広東省支局の管 轄下にある軽工業品進出口公司の分局と取引している とのことでした。また, 発生した利潤はほとんど中央 に収められるけれど, 中央で決められた利潤の一部は 工場に積立てられて, 福祉施設や修理や小改造とい。 たものにあてているようです。新増設のような大工事 の時は中央に申請して，資金や機材など割当てられる とのことでした。赤字を出した場合，例えば不測な事 故やら原料の不足などからですが，これに対しては中
央が赤っの補填をするそらです。

なお，新しい技術などを開発したり，採用したりし た時は，必ず同業他工場に公開するとのことで，製品 レベルの均一化をはかっているとのことでした。

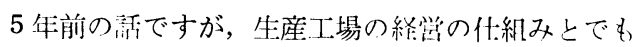
いうものは，そうは変っていないと思います。

川口昔は日本が工場を作って残してきているわけ ですけどね。

大江 逆説的に姛いますと, 結局, 消費がないんじ ゃないかと思います。といらのはバングラディッシニ にこの 2 月に行ってきたのですが，紙の消費は 1 人当 たり $0.6 \mathrm{~kg}$ なんですね。それでパルプ.工場, 製紙工: 場が 4 つあるのですが, 冬工場過剩生産で売れない儿 です。やはり購売力がないのです。中国の普通の人は 月給が 50 元とか 60 元です权。所得あたりの紙への支 出の比率は, われわれより多い位ですね。ですから本 当の需要はないんじゃないかと思いますね。

川口昔のソ連の状態と比較して考えてみたりした のですが，私がソ連にも520年程前にいった頃に作 っていた紙といらと，新聞用紙とあとは包装関係のク ラフト紙，段ボール原紙が立だったわけですね。ニー ズからいくと，やはり似たようなものではないか。佃 人が買おうといら物ではなくて，全体の国の絴済の中 でこういらものが必要だという物——新聞用紙はまた 別の意味があって，国として力を入れる。方们として は似たようなもので，ただ，原料事情があるからその 通りにはいかないという差はあるにしても，佃人が巊 おうといら紙はあまりないような気がしますね。

梯私もたまたま段ボール原紙を輸出しているもの ですから，一体どんな子うに使われているのだろら上 い.うことと，彼らの国内消費の紙上対外輸出の紙がど んなふらになっているかに非常に興味があって見てい たのですが, とにかく輸出する腑品の包装は, 彼らが 輸入したとおぼしき段ボール原紙を使っていますし 权……国内の物については，デパートとか食品术場 を見て歩いたのですが，草といらかワラといらか，ソ 一ダ蒸解のもので, どこまで煮たのかいい加诚なもの であまりにも違らレベルの紙を使い，国内はそ机で 我慢しているといら感じがあります。

それから紙なんて大して使っていないと㧈っしゃる 通り, 少なくとも生鮮食料品については, 全く無関係 です㸚。ごく一部, 薬品とかお菓子, 靴などにお粗末 な紙を使っているけれども，その位です。それから白

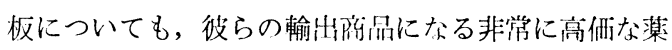
品などは素晴らしい。これは多分日本からの輸入だと 思いますが，ミラーコートのようなものを使っていま 
す。しかし，四以のは本当にお粗末で，ワラの板紙の ヒに白い紙を手張りしたという程度のものを使ってい ます。非常に差があるような感じがしました。

\section{紙の種類と製法及びその規模}

司会 それでは紙の種類と製法，規模というところ に移りたいと思います。前の分の質問でもありました ら遠虑なくなさって下さい。

伊東 私が行った工場で锠じたことですが，実にい い紙を作っているわけですね。上質紙, タイプ紙, 複 写用紙，スーパーがけしたコート紙とか，それはわれ われに見せるためなのか, そもそもそういう物を作ろ うと一生䀣命努力しているのか不思議なのですが，と もかくいい紙を作っています。むしろ中国の人のため に使うなら，もっと安い紙をたくさん作ったら良さそ うに思うのに，唒したような物ばかり作っていること が非常に不思議だったわけです。

若えてみると, ザラ紙というのは原料が GP でなけ ればならないので, われわれで言えば安いと思われて いる GP とかザラ紙などが，むしろ中国では一番高級 な紙であるのかもしれないのですね。むしろ化学パル プだけでできている紙の方が，安い，作り䍖いという ことかもしれませんが，それが不思議な印象だったわ けですね。

だけど，やはりそういう複写用紙とか七質紙を1日 当たり $2 \mathrm{t}$ とか $3 \mathrm{t}$, 多くても20〜30 $\mathrm{t}$ の替模で作っ ているのですから，とても国民全体を潤すまではいか ないだろうという感じでしたね。

司会 今のいい紙というのは, いわゆる上級紙とか コーテッドペーパーを作っているという意味なのか, あるいは上級紙とかコーテッドペーパーの品質特性に ついても，われわれの製品と比較して高級な紙だとい うのか, どちらなのですか。

伊東 そういう意味ではなく, 種類として上等な紙 を朋っているといらことです。地合は意外と良い紙が でているのですが，チリが目立って，日本では 3 級品 だろうというような紙ですが，グレードの高い物を狙 っているのです。

司会 それがどんなところで使われているんですか。

川口私はひょんなめぐりあわせから迎䆩館に泊め て頂いたのですが，机の上に置いてあるライティング ペーパーなどは実に站派です。トイレットペーパーで も非常に立派な，日本でもあまりお目にかかれないよ うなもので,びっくりしたのです。

司会掴製ですか。

川ロ そうじゃないかと思うんですが……。さっき
のソ連とイメージが違ってしまって，ソ連では行く先 々の便所でひどい目に会って……とれと大変な違い で，迎賓館といらことだから随分特別なんだろうなと は思いましたけど……

ソ連でもパンフレットとか, 博物館の案内などは一 态立派な紙が使われていたし，官用的な物にはいい物 が使われているんじゃないかな。だけど民衆の生活に はあまり関係ないんじゃないか……これは少し邪推 かもしれないけれど，そんな気がしますね。民衆と直 結した紙が作られているかということがちょっと疑問 でした。

工藤 確かに今おっしゃられた北京飯店で私たちが 部屋で使うトレイットペーパーは高級なんですよ。そ れから質の問題，これは今まで知らなかったのですが， 中国にも JIS と同じように国家基準があるのですね。 72 年だかに制定されているのです。これも品質要求 がベラ棒に高く，これに合っていないじゃないかと $\cdots$ 。

川口それはわれわれも実際に経験したことですけ どね。

工藤 今度買ってきた「造紙」という本, これは今 年の 2 月に発行されたものですが…...

司会 いくらで買ったんですか。

工藤 わずか 0.48 元です。日本円で 70 円位ですね。

司会 週刊紙が今日本で 150 円位でしょう。

工藤 一応文献的調査かもしれませんが, 新しいこ とが随分出ています。いわゆる TMP とか…., この 中に初めて紙の規格の問題が出ていました。海外の紙 の生産量も書いてあります。日本の紙の生産が，才イ ルショック後急に落ちたということまで書いてありま すよ。

渡辺 私も5 年前に見た所は, $1 \mathrm{~m} 600$ 位の古いイ 一ガンのタイプの片面コーターが 1 台あり, 両面やる 诗はまたもとに戻してもう1度機械を通すわけですね。 いかに紙作りが少ないとは言え, 中国の需要の何\%を まかなえるのかという感じですね。それで 12 段のス 一パーがあり, コート紙も通せば, グラシン紙も通し ています。その边の器用さは立派だと思ったんです が…...

それからライナーを作っている工場で, マシンにワ インダーがないんです。それで皆シートに切ってしま うのですね。またコルゲーターがなくて, シートでコ ルゲーターを作るということらしいんですけどね。全 く奇想天外という感じでしたね。

梯 私が見た段ボール工場もコルゲーターがありま せんでした。 
坂本 私は初めて見せてもらいましたよ。たばこ会 社でたばこの箱をパッケージするのに，シートで段ボ ールを作っているわけです。考えようによっては，小 ロットのものなんか実にいいんじゃないかと, 若干别 の意味で感心しました。

工藤 上海の江南造紙僘のサンプル帳があるのです が，こんな高級な紙を……。

坂本 結構な紙を作っていますよ。これなども現実 に‥これは天津ですが...作っていることは作っていま すからね。私が感心したのは, 比較的新しい76 in ク ラスのコンデンサーのマシンを見ましたが，これはコ ンデンサーとしてはなかなか立派な紙だと思いました ね。スーパーカレンダーも自国製ですね。製品のレベ ルもいろいろあるのが現実のようです。

私が団長でいったので先頭に立って，ボロい工場へ 入ろらとしたわけですね。そうしたら後のグループの 人が止めるわけです。そこへは入ってはいけないらし くて…‥段ボール屑からトイレットペーパーを作っ ている工場のようでしたが，そこを見てもらったら恥 ずかしいということのようでしたよ。中国は紙を輸入 していますが，一方ではローレベルの紙を相当量香港 スルーで東南アジアに出しているようです。

川口 やはりそういう調整がうまくいかないものだ から，東北地方で段ボール原紙を結構作っていて，そ れを輸出に回してしまって，一方では日本から輸入し ているというような，縦系列はそれぞれうまくいって いるのだけれど，横の調節がなかなからまくいかない といら面もあるようですね。

梯 天津の港へ行った時, 船積みの最中でしたが, ライナーのことを牛皮紙と言っていますが，輸入して またそれを平板にして志っているんじゃないかなと思 った位です。

司会 大体日本でやっている紙はほとんどやってい るといらことですか, 結論としては。

坂本 ノーカーボンは知りませんが，ほとんどある んじゃないですか。

司会 49 年の報告書に, 静電複写紙, ノーカーボ ン紙等のサンプルを見ると, 相当なできばえであると いら記事が出ているのですが…...

伊東 それはむこうの研究所の女の人が発表したも ので，お前の所でもノーカーボン紙を作っているだろ らかと聞かれたのですが，私は專門外だったので，あ あそうですかと聞いて州ってきただけです。サンプル だけ見せてくれたんです。

司会 製造はしてないわけですね。テスト的に作っ ていると…。
大江 ジアゾの複写紙は使われているんですか。

渡辺 どうですかね。どういうふらなものをぬるル だとかさかんにやってましたけどね。

片倉 日本でこの頃複写というのが非常に発㓐して いますが，複写紙などは盛んですか。

奈倉 カーボンペーパーを入れるといら複写しかや らないですね。ですから私達が漢陽造紙廠へ行った時 も, 複写紙を作っているというのでジアゾ系の何かを 作っているのかと思ったら，とてもじゃなくて，薄い 米坪 $17 \mathrm{~g}$ 位の紙をのろいマシンで抄いているわけで すね。買物をしても, レシートなど出ないから, 自分 たちの管理のためにきちっと受け取りを書きますが, 必ずカーボン紙を入れて書く。控えの方に出ないと， カーボン紙の使っていない所をまたわざわざそう人し なおすというようなことをしているくらいで, 複写と いっても旧態依然としたもののようです。

司会 TPC みたいなものはないですか。

梯 見ないですね。日本の陌社は，日本から持って いてそれを使っています。今回䍋習会をやった時，教 科書をこちら側から送っておいたのですが，それを中 国語に訳して受講生が皆持っているわけです。やはり タイプより薄いような紙にカーボンをはさんで, タイ プを打ち，それを教科書にして使っています。ですか ら，いわゆるコピーというのはないんじゃないですか。

片食 日本ではタイプライターを使らでしょう。あ あいらのはむこうではどうなのですか。

坂本 公式文書はタイプライターで来ますね。

渡辺私, 5 年前に行った時, 向こうの人がバガス のやり方とかワラの素方などを話してくれたのですが， それを黒板にグラフなども，実に器用に書きますね。 あれだったらコピーなんかいらないなと思いました。 日本人だったらあんなことやらずに，配ってあるから それでといらところでしょうね。

司会 新聞を売っていたり，配達はどうなのですか。 われわれ壁新聞しか知らないんですが。

宮下 人民日報など中央紙のほか, 地方ごとにいろ いろ出しているよらで, 北京では北京日報, 北京晚報 といら形ですね。私のいた時は郵送なんです。ホテル や事務所にはまとめて配達してきますが，それも全部 郵便局経由で入ってきました。

司会 一定の個所だけに送っているのですか。

宮下 家庭でもとっているのですが，まだ中国では 各家庭でとっているということはないのです。日本で 言うと町内会のような所で迴し読みするとか, 掲示板 に裏表掲示して迴し読みしていますね。

梯 北京の王府井では人民日報を売っていました。 
新華社でも莣っていますし……

宮下 北京などでは駅前にスタンドがあって, 売っ ています。ただ，当持は外国人に売っていいのと悪い のとあって，あれが欲しいと言うと駄目と言われたり， 買っていいのは限られていましたね。

楠田 ただ，一般に読まないですね。というのは日 本だと，交通が電車とか車なので読める。ところがむ こうは自転車だから読めないんですね。あとは電灯が ないですから，見えませんし……。夜は夏など皆外で 遊んでいるわけです。暑くて部屋の中にいられません よ。

川口 漢字ばかりだから読みにくいんじゃないです か。壁新聞は見えたけど，そのとなりは写真ばかりあ っ $\tau \cdots \cdots .$.

工藤 写真が多いですね。

宮下 中国の場合，ラジオを非常に有効利用してい るようですね。普通の日の朝出る新聞の主要な記事は, ラジオで流しちゃうんです。遠隔の場合はゆっくり畵 きとりができるくらい。最近はやめたそうですが，私 がいた頃は 2 度も繰り返してゆっくり読みますから， 私共が中国語を勉強するのにちょらどいいんです。

それですと，例えばチベットであろうと瞬時に届き ます。新聞ですとチベットまで 1 週間近くもかかって しまうから，中国では方言や地方語も多いし，娱楽も 少ないので, そういう点で語学教育, 思想教育, 娱楽 を兼ねて有效利用しているのでしょうね。

それからさっきの複写の話で言えば, 新聞は主要都 门j, 上海, 広州, 瀋陽, 西安などの主要都讯にファク シミリで原板を送り印刷している。従ってほとんど北 宗と闹時に印刷している。まだ一般的ではありません が。

工藤 面白いのは皆工作手帳をもっていて，この手 帳の普及は素晴らしいですね。ただ，ポケット版です から，書いているうちにすぐ終わってしまうと思うの ですが……技術交流の人たちなどは大きな手帳です が，先生たちはポケット版の手帳を出して……女性で も持っていますから，あれは相当部数出ているような 気がしますね。

福田 毛活録は皆持っていたのですか。これは相当 な紙の量になりますよね。

工藤 3 億冊ですね。

\section{需要と供給の状況}

司会 需要と供給の状洗という話が今出ているので, 続いてこの問題についてお願いします。

大西 中国はこれから 4 つの近代化を急速に推し進
めるに当って各種の紙が沢山䈍しい。急いで増産態勢 をとりたいが，さて先ほど述べたような現海を踏まえ て，どのようなケ问でこれを実現するか。手工業的な 地方小工場は別としまして，主力工場の生産能力を倍 增したい，また原木への原料転換によって工場の近代 化を進めたいというのが彼らの念願で, 先進国の技術 を導入したいポイントがこの辺あると思われます。

後藤 先程ちょっと申し上げたように 5 年前の話な のですが，400万 $\mathrm{t}$ 弱の生産のうち，その一部を香港 マーケットに出していました。需給関係では約 $20 \%$ が不足し，それを輸入していますが，その中核的なも のは輸出棝包用の包装用紙, 段ボール原紙であり, 洋 紙ではコーテッド紙が主体でした。

最近日本からどういう紙が輸出されているかという ことですが，昨年の実績で，板紙関係が約 16 万 $\mathrm{t}$ ， 洋紙関係が 8,700 8,800 t 出ています。やはり段ボ 一ル原紙が中心で段ボール原紙が約 $145,000 \mathrm{t}$ ，残り が白板紙が約 $20,000 \mathrm{t}$ ，紙では一番多かったのが， アート紙で約 $3,000 \mathrm{t}$ ，上質が $400 \mathrm{t}$ ，新聞用紙が約 $2,000 \mathrm{t}$, クラフトが $2,500 \mathrm{t}$ でした。今年の見通し で寸が，洋紙の方に関心が強く，今年の輸出予想が洋 紙が 25,500 $\mathrm{t}$ とされています。内訳は新聞が 6,000 t , 上質紙が $13,000 \mathrm{t} ，$ アート紙が $6,000 \mathrm{t}$, クラフト $500 \mathrm{t}$ ，板紙関係がちょっと減って，これは国内需給 のタイト化にもよるのですが，クラフトライナーが $75,000 \mathrm{t}$ ，パルプしんが $50,000 \mathrm{t}$ ，コート白ボード が $15,000 \mathrm{t}$ その他板紙などで $500 \mathrm{t}$ 位出るだろうとい らことになっています。

昨年までは世界的に競合が強く， 沙沉も悪くて出血 輸出でしたが，今年に入ってから価格が上がってきて， 大体採算のラインに乗ってきつつあるといら状況です。 今後とも日本に期待するところが大きいような話です。 特に北欧のものが，難かしさを增しているため，日本 へ指向してきているといえると思います。

坂本 今の扔話の中の統計で, 香港スルーのは入っ ているのですか。

後藤 いえ，これはダイレクトです。

坂本 その外に香港スルーが相当量あるわけですね。

後藤 あると聞いています。今申し上げた数字は日 本から中国へのダイレクト分の実績予想です。板紙輸 出先の大体 $60 \%$ 近くが中国市場です。

工藤 本が入荷するとすぐ売れちゃうという光景は 去年今年ずっと体験していますね。

福田 大体こんな紙ですか。

大江 これよりもっと覀いのもありますが，もら少 しいい紙を使っているのもありますね。 
福田らょっ上色が付いて, 不透明度がよくないで すね。

楠田 3 冊ぐらい買ってきたのですが......

司会 そういら分野の本しか売ってないのですか, もっと楽しい本は……

楠田 アート紙を使った素晴らしいのもあります。 坂本 外国人用にアート紙を使ったのはあります。

ただ，それはインポートされた紙のようです。製版 技術があまり良くないようですね。あまり素晴らしい 印刷とは思えませんね。

楠田 例えば地図なんかは極めて精細な, こんなに 厚いのを入れていますね。主として外国人が買ってし まいますね。われわれ素人から見れば，地図としての 印刷は素晴らしいですね。

宮下 中国の今年の国家予算の支出総額が 1,120 億 元，そのらち軽工業と紡績工業の投資額の比率が 5.8 \%です。昨年度が $5.4 \%$ なんです。 79 年度の 基本建 設予算の支出は, 農業, 軽工業, 重工業の順で, 重工 業の比率が前年度より減って, 農業と軽工業が堌えて います。軽工業のうち紙は，79 年度の建設案 は日 産 $50 \mathrm{t}$ 以上の製紙工場を 7 つ作る，これ以外に地方も小 さいものは作っていきますが，国家訃画ではこういう ことです。

輸人で板紙が多いのは, 輸虬蔺品の包装用として明 らかですが，最近変わってきたのは一般の紙，これは 国内生活の水準を向上させるのに，印刷関係，雑誌関 係の用紙が非常に上がっているためと思います。従来 は輸出一辺倒で, 重工業を先にやろうといらことだっ たのですが，やはり民度を高めるといら装求に押され ているようです。それから中国では輅工業の方が，よ り利潤が早くあげられると言っています。

川口 外貨を稼ごうかということもきっているよう ですね。

司会こういら雑誌 (中国画報) はどの位出してい るのでしょらかね。

工藤 それは外国向けですね。メイドインジャパン のもあるんです。発行所は日本になっていますね。

渡辺 印刷は向こうでやっているんでしょう。各国 語で印刷している所を見ました。

楠田 中国は輸出包装の水準を上げねばならない。 そのためには包装の産業基盤を確立しないとできない のですが，輸出包装だけを良くして国内包装が悪いと いうのでは実は成り立たない問題ですから，私共は輸 出包装を上げるためには国内の水準を上げないと抜本 策にはならないぞと, 軽工業と対外貿易を強調してや れということで，基盤確立に重点を置いて指導をやっ
ているのです。少しずっ分かってきているようです。 輸出だけは良くする，片方はどうでもいいというこ とで成り立つものではないのです。

ところが先生方は苦しまぎれに，とにかく輸出だけ は欧米のマーケットに出て, 品質も技術もデザインも ということでやりたい。しかし，それは無理なのです。 それから面白いのは東南アジアは, 日本のよりむし ろ中国の紙の方が，つまりグレードを下げた紙の方が いい。例えば私この間，中国に行く值前にパキスタン に行ったのですが，パキスタンのトイレに入ると，力 ラチは全部中国のトイレットペーパーばかりです。や はり中国位ので間に合わせようといらことで, 天津新 港でどんどん紙が輸出されています。いいものを入れ てグレードの低いものを出すということですね。

司会 デインキングはどの程度やられていますか。

坂本 量的にも少ないですよね。私の見た工場では デインキングどころではなくて，苩われわれの所は綿 ボロを使っていたわけですが，綿ボロだとカルシウム でも油はとれるのです。しかし，彼らはカルシウムも 使いませんよ。水だけで煮ています。綿ボロも水だけ で煮ていますから，確かにアカはとれるんです。だけ どにおいがしますし……。ブローパイプやブロータン クを作ったりしていますけど，とてもにおってどうし ようもないですね。

川口 古紙処理といらことについて関心はあるよう ですけどね。さっきのお話のように消費量が相当程度 いかないと, 古紙のリサイクルといらのはあまり問題 にならないんですね。

福田 われわれ日本の状態から見ると, かなり低い レベルだということは，逆に洘えるとそれだけ無限の 问能性があるともとれますが，だけどそこまでいくの に大変ですね。

川口大変だと彼らもいってましたね。技術の唒で は日本と比べても大変な通れだと……だから一生懸 命学ぼうと思っているのだ，協力してくれと……

福田 だけど日本の場合考えると各産業全体のレベ ルが一斉に上がって, 初めて可能になることが多いで すね。

川口 だから 1 つだけ良くしようということはやっ てみたけど，それでもうまくいかなかったということ で......。

\section{今後の課題}

司会 そうすると今後の課題という話に人ってきた と思らので, 中国関係についての紙パルプ産業におけ る今後の課題ということで話して頂きたいと思います。 
宮下 紧料関係では，林野打が州国と技術父流をし ていますが， 2 年前，ちょっと古いのですが，中国の 森林蓄積は80 億 $\mathrm{m}^{3}$ といら話しでした。そのほとん どが東北地方で, あとは南の方の福建, 湖南, 貴州な どの山奥でして，華北大平原や愓子汇下流など人口が 密集している地域には木がない。最近は鉄道もかなり 敷いて，鉄道網の整備をしていますが，森林が相対的 に少ないうえ，辺境にあり，輸送の問題もあり，造植 林しているといっても，当分国内資源だけで需要をま かなうのは大変なことだと思います。

一方, 生活水準があがり, 民度が高まってくると, トイレットペーパーの例にありますように, 現在は都 円でもほとんど使っていないと思われますものが，都 门部で要求が出てくるだけで莫大な量になりますし, 尚等教育, 科学技術の普及など生活, 文化の向上とと もに紙の使用量は急速に多くなると思います。

增産への投資としては，今年度に50 t 以上の規荧 の工場を 7 つ作ることになっていますが，この位では 道いつかない恐れがある。ただ，政策的にこれまでの 重工業最優先彩から，舲工業を見㨁し，力を人れると いっていますので，製品輸入だけでなく，プラントや 徖料輸人など外国への依存度が高まる可能性がありま す。その理由としては, 过境の木材を切るより, 沿岸 蔀で輸人原料による立地の優位性が考えられることと， 草本系の資源については, 不勉強ですが, 食糧增産が 大命題ですので，半野淿でパルプ资源用としての增産 はあまり期待できそうになく，食糧作物の幹，茎の有 效利用に留まるのではないかと思われるからです。

中国の国際父流が予想以上に活発ですが，多くなれ ばなるほど, 生活水準向上の欲求が出てきますので, 意外と早い時期に紙パルププラント導入問題が生じて くることも考えられます。導人する場合は消費地であ る沿岸淿が考えられますが，日本は地理的にも近く， 技術的にも優れていますので，大いに有望と言えます が，原料関係ではいずれにしても北米や北欧に依存せ ざるを得ない触みがあり，この問題を含めた北米等と い镜合問題が起こるのではないでしょらか。日本とし ては原料に手当をしたプラント輸出を考えるのが面白 いと思われます。

プラントを出して, 直ちにブーメラン効果が出ると は常識的には考えられないけれど，これまでの例から して国内消費を節約して輸出を図ることも考えられな くはないと思います。また，南方林材は，中国との間 で競合することがあるかも知れませんね。

司会 油でも GG 取引などといらのもやっているし， また中国の文化レベルの向上とともに紙の必要もある
ので，中国と $\mathrm{GG}$ 取引などをやって，日本の余剩分は きちんと出してしまえば国内も安定するし……

そういうことについて何かお考えありませんか。

宮下 中国は商売上手でして，例えば油などでも大 体中国の輸出といらのは，インドネシアのミナスにあ わせた価格だったのです。ところがこの秋から改訂さ れたので：ミナスよりも高くしてくれということで, 重質油なもので，私ちょうど 48 年当時にいたオイル ショック時期を見ると，農協の会長とか，とにかく日 本から来られる皆さんが国家代表みたいな感じで油を 下さいと言っていたのです。

ところが 50 年過ぎてくると，重質油は要らないと， 一将 800 万 $\mathrm{t}$ 位いっていたのが 600 万 $\mathrm{t}$ 位まで下がり ました。それで長期契約を結んで， 85 年まで契約し ましたが，そういう価格ではそんなに買えない。

資源問題として，長期的には多角化しないといけな いし，重要性は增す一方だと思うのですが，そのジグ ザグのところがどらなるかといらことです。

共同開発などはとくに海底油田など，向こうは陸卜 の採油とかボーリングについては技術水準が高いと聞 いていますが，海底油田はあまり経験がないというこ となのです。そういう形で取引きできれば兒返えりと して出すことができると思います。

川口やはり優先的にアメリカが手をつけているわ けですよね。日本がどこまでおこぼれをもらえるかと いうところではないですか。

宮下 中国の外国に対する技術水隼の詊価といらの はアメリカが 1 位, ヨーロッパの先進諸国が 2 位, H 本は 3 位ですね。にもかかわらず日本の取引が多いの はやはり近いからでしょらね。生活習慣とかも近いで すし……でも新日鉄が武漢の製鉄所で圧延工場をつ くっていた侍期, 日本から 800 人位中国に行っていま したが，フランスも大体 800 人位だったそうです。一 見日本だけが多いようですが，技術的專門的な面にな ると各国から同等に来ているわけです。観光, 友好親 善では日本が第 1 位ですけれど。

川口 そういう意味でハッパかけているんですね。 日本の協力を是非得なくちゃならないんだと……

だけどアメリカとかヨーロッパが今非常に㗢きかけ てきているから, 日本は余程頑張ってもらわなくちゃ 困るよということで……商売上手だということです よね。

宮下 取引上の価格のことを別にすれば，中国は非 常に情があって……取引きが長ければそれなりのメリ ットはあるはずです。ただ価格上の問題ではたたかれ ますがね。 
工藤 確かに向こうの信用を得ると, 特命的にやる といらケースがあるようです。われわれが向こうと技 術交流をやっていると，現在世界で最先端をいくよう なものを欲しいとすぐいいます。そんなの無理だよ。 機械だけ新しいものをいれても, 運転保守できないよ と説明するわけです。関連するもののレ心゙ルがすべて 整うまでは，ここらへんで，まずスタートしなければ 駄目だといらのですが，なかなか言らことをきかない ですね。

しかし，最近は，はじめの話より少しずつ小規模に してきましたね。初めはバカでかいことを言っていま したが，それが実態に伴わないといらのが，少し分か ってきたんじゃないかといら気がしますね。

これは他のプラント類からの経験なんですが，プラ ントを入れたはいいけど動かないといらのが随分あり ます。それから今お話に出た武漢の製鉄所も，電気が 来なくて動かない，こういら問題が非常にあるようで すね。

宮下 電力ももう少し範用を広げて,わりと遠距離 の送電も……

川口 大分計画立てているようですね。

工藤 先程の $50 \mathrm{t}$ 以上を 7 カ所という中に，発電 所を設けるなどといらのが入っています。電力が足り なくて動かないといらのがあるのです。あれは今年度 中にできちゃらんですね。1台 $50 \mathrm{t}$ のを 2 台といら工 場もありますね。そのクラスの抄紙機は全部国内で作 っていますよ。

私共上海の造紙機械工場へ連れていかれたのですが， ここで意見交換をしたいと言われました。彼らはある 基準を設けているわけです。スピードはいくらと決め て流して作っているんです。それを最新的なものに変 えるにはどらしたらいいかといらことで意見を言って くれというわけです。

福田さっき森林面積が 80 億 $\mathrm{m}^{3}$ と諳われました が……主として一番多いのはどこなんですか。

宮下 東北地方, 昔の満州ですね。

福田 私, 戦前に満州のダフリカカラ松で人絹パル プを作るといらので, 大学時代大分研究をやらされた ことがあるのですが，天然ボウ硝も出るといらんです。 方々の大学の研究室でも随分熱心に研究されたことが あるのですが，そらいらのは今問題になっていないの ですか。その当時は今よりトランスポーテーションの 事情などは悪かったと思らんですけれども。工場をそ の近くに建設しょうといらことで，いろいろ研究をや ったことあるんですが，最近は一向にそういら話が出 て来ないのでどらなっているんだろらなと思んですけ
ぞ。

楠田 昔の話ですけど, 切り出してからのトランス ポーテーションの小運送が問題なんです。小運送が照 車ですから輸送能力がないんです称。幹線まで来れば いいんですけど。ですから私は石炭担当だったんです けど，それは今でも解決してないと思うんです。それ から湿地带ですから夏は全然動かないとか，いろいろ な悪条件があるものですから，凟材，原料があっても， その有効利用への物流関係が非常に遈れているのです。 物流が伴なわなければ駄目だと言うんです。

司会 ハイウエイの建設なんていらのは全然行われ ていないのですか。

川口 やっているんじゃないですか㱛。そのくせ輸 送のコストといらのをどら考えているのか分らない点 もあるんですよ敞。アシの原料を $1,000 \mathrm{~km}$ 伦といら 人もあり， $2,000 \mathrm{~km}$ 位先からもってくるといら人も あるんだけど，そらいら運貨はどうなっているんだろ うと思います。

雨宮 その辺は価格差があるようですね。例えば湖 南省から東北，天津へ持ってくる場合，アシが $1 \mathrm{t}$ 大 体 240 元位，それが地元だと 80 元位といらことです から，どの程度輸送費が反映しているのかは分かりま せんが，大体 3 倍位にはなっているようです。

川口共産の計画経済だと, 樺太からウラル越えで 持っていくといらょうなことも, 運顀を考えたら大変 だと思らんだけどちゃんとやっていくといらょうなこ ともあり，われわれの勘定とは少し湋うんじかないか と害ってたんです。

司会 中国はコストといらものもちゃんとやってい るんですか。

川口一応あるといら唯です。やはり輸送費といら ものは考えているはずだと確かにっってました。そし たら随分高い物になっちゃうなといらことでしょうね。

奈倉 ただ，国家のユーザーに対する価格だけはき ちんと押さえていますね。私共が肳和 50 年に矨った 価格では印刷用紙が $1 \mathrm{t}$ 当たり 1,450 元, ロール紙が 1,250 元, 新聞用紙が 900 元と言っていました。

では工場から国家がいくらで買いトげてくれるのか といったら, 全然別の話を持ち出して, 北京ではトマ 卜を生産者から国家が 8 円で買い上げて，消費者には 5 円で出している。トマトのとれる時ととれない時と あるからと言らんです。そらいう原資はどうするのだ ろらと言ったら，輸入紙を安く買った時などはその調 整金が割合多く出て，買い上げ価格が変わってくると いら話をききました。

福田 中国の立場で見れば，今後の最大の課題は物 
流でしょうか。

雨宮 原料問题もありますし，噮境問題も企くしい っていい位やっていない。今後は相当なインパクトに なってくるんじゃないかと㤍いむす。

川口 水の関係にしても，まだ游菊地帯はいいけれ ど，川沿いがたくさんあるわけでしょう。あれは污し ほうだいといらわけにもいかないだろうけど，当分は 切実じゃないですね。

伊東 川の大きさもケタ䔔いに大きいのではないの ですか。

川口今の上ころは淎品の同收しいうメリットの方 を䒓えているんじゃないかな。

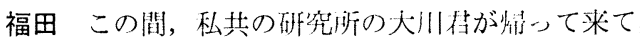
工場が廃水を川に流しているのをみると，廃水より川 の水の方が汗ないといらんです。

司会 㛫子江というのはえびがたくさんとれるんだ から，そら汗ないとえびがいなくなっちゃらでしょう 小。

雨宮 ヒ海あたりの長汇のブランチの所は名物のカ ニがたくさんとれていたのが非常に少なくなっている というんですけど……紅衛造紙遫では今，回収工程 を検討中ですし，民豊造紙では间っています权。それ から活性污泥とか，凝沈とかもパイロットプラントを 動かして，上にかく良くしなくちゃいけないといらこ 上ですから，间初的には，かなり大きな間題になって いるこ上は確かです。一萑大きいのは勃游湾の活染だ と思いますが，これは国家、继で既に命命が出ている ルだそうです。可算がどうなりますか。

工藤やはり公罡にある柱度関心を持ってい专すね。 にだ堄笑には金がないというのが一采大きいですね。

伊東 だけどl場一行って，例えば排水の SS は一 体どの程度かと聞いても，幹部は誰も矨らないんです。 口ではっうけれど現害にはそうでもないんじゃないか という気がしますね。

川口 基準とか何とかを先にしたということじゃな いでしょうか。紙の規格でもそうで，まず規格が忺き ちゃって，それから追いかけていって合格率 70\% 位 上, 最近のコンデンサペーパーなどもそんな状沅です ね。顺就逆に進んでいるんでしょらね。

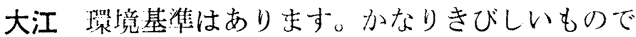
于。

川口よその目りものと準用したようなものがある んじゃないかな。

工藤 今後作ろらという工埸に対しては，その規定 を適用しようといらことははっきりしていますね。

大西 最後に訪問した天津造紙僘では，アシを原料
にしてパルプを作り，上質紙，板紙などを日産 $200 \mathrm{t}$ 作っていますが，增産と共に公菑も何とかしなけ㜾ば ならない状洗になってきておりました。蒸堂廃液は, 現在の所, 垂れ流しのままなので, BOD, COD など は，日本に比べて 2 ケタも高い。これをどうするかで， 1 日半も討論したような状態でした。

福田 宮下さんにちょっとお同いしたいのですが， 中国というのは省にわかれていますね。これは中央集 権的なんでしょうか。あるいは各省ごとに自給自足す るといらのは地方分権的な感じもするんですけど。

宮下 政治的には中央集権です。経済的には完全に 地域経済です。昔は戦争に備えるために，沿岸部から 第一線, 第二線, 第三線として工業を整備していまし た。まず都书部がやられた場合は第二線に下がって防 衛するという具合です。それともう1つは, 中国はも ともと外国が入ってきて工業を興こしたということで， 沿岸部に偏重しているんです。それを是正しないとい けないということで，例えば武漢よりも上流の山合い から平野が開けた直後の宜昌市, 沙市といら所, 内陸 部で昔は数千人の寒村だった所を 30 万の工業都边に するとか，中小の工業をかなり地域的にやっています。

それはおそらく輸送のネック, 資源の分布, 昔は石 炭は南方では採れず，楊子江以南はないと言われたの が，最近は採れだしたといらこともあって，なるべく そういうものを多角的に使って，輸送や経済効率を这 くしようという点では効果的だと思いますし，今一つ は人口の地域分配のこともあるかと思います。

福田 プラントを作ったりというのを中央政拊で集 めて，刘外的には 1 本で交沙するんですか。

宮下 1 つは中央が直接投資する重点部門，それか ら闰じ检鋼業でも地方が独立でやる，それは規模も小 さいわけですが，そういう2 通りがあります。武漢の 鉄鎆とか上海の宝山は，中央の直接投資です。重工業 では比較的そういうのが多いですが，軽工業に近くな ればなるほど地方に権限移譲されています。

川口 水力発電所計画などたくさん持っているわけ でしょう。これは全国的でしょう。しかもああいうも のはつないでお互いに融通するといらこともあるでし ょらからね。

工藤 各省は各省で計画を持っていて，それが自分 の省でできるものはやるんです。ところが大きくて金 がいるというものは，中央へ持っていかなければなら ないわけです。

宮下 今問題になっているのはまさにそれです。各 省とも自分のところに欲しいので，いろいろ出してい くんでなかなか配分がうまくいかなくて， 5 年たって 
まだ完成しない。その間いろいろ浪費しているので， それを整理統合して，重点的にやろうというのが，昨 年あたりから調整と言われることの一つです。逆に早 く完成したいために，今年度使い切らない資材まで多 目に要求したりといら矛盾がいろいろ出ているという 話をききます。

片甾 われわれは，中国のインフォーメーションを 欲しいわけです。それで今北京の図書館だけがずっと 昔からここにある中国画報を送ってくれていて，こち

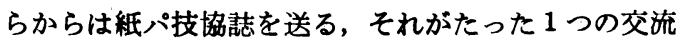
なんです。中国で紙パ関係の学協会があって機関誌を 出しているとすれば, 出している所とコンタクトして 交換でもすればいいと思うんです。

も51つは中国の個人会員を増やそうということで, 增やそうと思ってもどこを中心としていいかわからな い。学校とか協会，あるいは役所が中心になっている のか。また，個人会員が外国のそらいら所の会員にな るのは昔はやかましかうたけれど，この頃はそうやか ましくないといら話をきくわけです。そこらへんの状 洗がどらなっているのか皆目わからないで, お知恵を 措借できれば……思います。

丽宮 機関誌があるかないかは分かりませんが，中 国の製紙関係は全国組織といらのはありますね。これ は造紙学会, 理事長は軽工業部の副部長の王毅之さん で, その下の戴家璋さんが副理事長で, この方とコン タクトすれば何らかの道は開けるんじゃないかと思い ます。国家科学技術委員会の方ともコンタクトされる とか, いろいろルートを分けてトライされれば，その 弓ちに反応があるかと思いますが，括そらく 2 年か 3 年かかるでしょう。すぐにはレスポンスがないと思い ます。

片余 中国がそらいうことを外国にアナウンスする のが許されているのかどらかが分からないし……

司会 大使館に聞いてみることと，技協誌を何百冊 か, 北京に配布してくれといって送って，返事をもら らということも，まず実行してみたらどらですか。

宮下 造紙学会宛に直接送られた方がいいですね。

個人会員として雑誌を買らことは難しいんだろうと 思います。

司会 省の数だけはそこに送ってみるといいと思い ますが。

川口 造紙学会は軽工業部会に非常に密接な関係が あるんじゃないですか。

宮下 そうですね。

川ロそこがいい空口になりそうだな。

宮下，中国は非常に繸割りが行き届いていて，横の
連けいが意外と難しいんです。

栐田 包装の方は, 実は前は対外貿易部, 今後は軽 工羕部の方になったのですが，中国包装技術協会とい うのを作ろうといらことになったのです。今の綎割り をやめるといらわけではないのですが, それぞれの軽 工莱部関係と対外貿易部関係とで中国包装技術協会を 作って，アジアで連盟に加盟の準俌を進めています。

中国に紙パルプ技術協会を作れと示晙されるとよろ しいんじゃないかと思います。私共は 3 月に私が行っ て示唆し，今は包装技術協会を作るということで進め ています。

司会造紙学会が，日本の紙パルプ技術協会と似た ようなものなんでしょう。

川口連合会と技術協会と両方一緒になったような 感じですね。相当権威のあるものらしいです。

工菠 紙パ技協誌は知っているようです。ところが, 言葉の問題があるんじゃないかと思います。例えば, 私たちは紙パ技協誌の何年の何月号のあれを説明して くれと,むこうからきかれたことがあります。とうも 中国では，1冊あれば事足りちゃうんじゃないかと思 いますね。最近，彼らの日本語に対する肉心はものす ごいんですよ，ラジオで一生隹命勉強してますからね。 彼らのことばの水準が上がってくると, 読み出すと思 います。ただし，個人会員は無理だろうと思いますね。

司会 個人会員でなく，1つの工場で 1 冊とっても らっても, 工場の数は 1,000 とか 2,000 以上あるとい うんだから…...

工䔉 ある人が機械学会誌をやっと買ってもらえる ようになったといらような話をしていましたから，あ る程度眫読しはじめてくると各工場で 1 冊といら気運 は起こってくると思います。

司会 では時間も来ましたので，最後に，大西さん むナびをお願いします。

大西 2 週間彼等と付き合っている中に,「外国人! という感じが全然しなくなり, 親嘁か友達という感じ がしてきました。血は水よりも湌しと言いますが，言 葉は通じなくても気持は通らものです。一衣带水の隣 国中国には，10 億の民がいて，これからまっしぐらに 先進国に追いつこうとしています。この現実を私達は 見過すわけにはいきません。中国側でも余りあせらず, 一歩一歩確実に進んでほしいと思います。

あれだけの大国の軌道修正をしながら，目的地一誘 㱏して行くことは，為政者にとって並み大抵のことで はなかろらといらのが, 私の実感です。

司会 ではこれで終りたいと思います。有難うごさ いました。 